\title{
CLINICAL AND PATHOLOGICAL KIDNEY ASPECTS OF SICKLE CELL ANEMIA AT DAKAR: STUDY OF 11 CASES OF RENAL BIOPSIES
}

\author{
$\mathrm{Ka} \mathrm{EF}^{1}$, Fall S${ }^{2}$, Cissé $\mathrm{MM}^{1}$, Dial C ${ }^{3}$, Berrada $\mathrm{H}^{1}$, Keita $\mathrm{I}^{4}$, Tall AO ${ }^{1}$, Niang $\mathrm{A}^{1}$, Ndiaye FSD ${ }^{2}$,Diouf $\mathrm{B}^{1}$. \\ ${ }^{1}$ Nephrology department of Aristide Le Dantec Hospital, Dakar, Senegal \\ ${ }^{2}$ Hematology Clinic Unit of Aristide Le Dantec Hospital, Dakar, Senegal \\ ${ }^{3}$ Pathology department of Aristide Le Dantec Hospita, Dakar, Senegal \\ ${ }^{4}$ Nephrology department of Albert Royer Children's Hospital, Dakar, Senegal
}

\begin{abstract}
Few studies are devoted to the practice of renal biopsy in sickle cell nephropathy; our objective was to determine the histological and evolutionary patterns of renal lesions in sickle cell patients who underwent renal biopsy in Dakar.

\section{METHOD}

This was a retrospective multicentric study (conducted from December 2009 to August 2011) on renal biopsies performed on sickle cell anaemic patients at the Nephrology Department of Teaching Hospital Aristide Le Dantec and the Albert Royer Children's Hospital. The histological, therapeutic and evolutionary data were analysed.

From the 292 total renal biopsies, $11(3.80 \%)$ were performed on sickle cell patients (6SS, 1SBth +4 AS) with a mean age of 23.1 [13-51 years]. Nephrotic syndrome was the indication of renal biopsy in all cases. Focal segmental glomerulosclerosis was the most frequent histological finding (five cases), followed by a combination of various specific lesions (hypertrophy of glomerular and peritubular capillaries), minimal glomerular lesions (three cases), membranoproliferative glomerulonephritis (two cases) and extra-membranous glomerulonephritis (one case). Complete remission after treatment was achieved in seven cases and one patient expired. Three patients did not continue with follow-up appointments.
\end{abstract}

\section{CONCLUSION}

Renal biopsy is not very frequent in the course of sickle cell anaemia and in most cases it is performed because of nephrotic syndrome. The histological findings are diverse with a predominance of focal segmental glomerulosclerosis.

\section{KEYWORDS}

Glomerular disease, sickle cell anaemia.

\section{INTRODUCTION}

Sickle cell disease is an inherited haemoglobin disorder causing acute rheological and chronic visceral disorders, involving kidneys in between four and $18 \%$ of the cases [1].
Few studies on renal needle biopsy in the sickle kidney disease are available, particularly in Africa where sickle cell disease is a public health problem. Our objective was to determine the histological and evolutionary patterns of renal damage in sickle cell patients who underwent renal biopsy in Dakar.

Corresponding author: Professor Ka Elhadj Fary: Nephrology department, Aristide Le Dantec Hospital, BP 6840 Dakar étoile (Sénégal), Phone : (+221)765937086, Mail: efaryka@yahoo.fr 


\section{PATIENTS AND METHODS}

This retrospective multicentric study was from December $1^{\text {st }} 2009$ to August 1st 2011, and included sickle cell patients being followed at the Nephrology Department in Ariside Le Dantec and the Albert Royer Children's Hospitals in Dakar who underwent renal biopsies. The biopsy specimens were examined in the pathology department of Aristide Le Dantec Hospital with light and immunofluorescent microscopy. Epidemiological, clinical, laboratory, biochemical findings (urea, creatinine clearance by Cockcroft and Gault, protein electrophoresis, quantitative 24-hour urine protein), histological, therapeutic and evolutionary data were analysed. The creatinine clearance was calculated using the MDRD formula and chronic renal failure defined according to NKFK/DOQI [2]. The complete remission (CR) was defined as proteinuria less than $0.3 \mathrm{~g} / 24 \mathrm{~h}$, partial remission (PR) by a proteinuria greater than $0.3 \mathrm{~g} / 24 \mathrm{~h}$, and persistent proteinuria and relapse by the reappearance of the proteinuria more than $3 \mathrm{~g} / 24 \mathrm{~h}$ after a complete or partial remission.

\section{RESULTS}

From a total of 292 patients who underwent renal biopsies, 11 were sickle cell anaemic, of which seven were sickle cell carriers (6SS, 1SBth + ) and four had sickle cell trait syndrome (4AS). There were six women and five men with a mean age of 23.1 years [13-51 years].

Patients with sickle cell SS had chronic osteomyelitis (two cases), macroscopic hematuria (two cases) and cholecystectomy (one case).

Renal manifestations were characterised by nephrotic syndrome (all cases) with an average proteinuria $6.01 \mathrm{~g} / 24 \mathrm{~h}$ $+/-2.84$, combined hypertension (one case), chronic renal failure (six cases) and microscopic hematuria (11 cases).

The mean creatinine clearance was $72 \mathrm{ml} / \mathrm{mn}-1$ [11-186ml/ $\mathrm{mn}-1]$, and chronic renal failure was classified as Stage 1 in $46 \%$ of the cases, Stage 2 in $9 \%$ of the cases, Stage 3 in $18 \%$ of the cases, Stage 4 in $18 \%$ of the cases and Stage 5 in $9 \%$ of the cases. Anaemia was found in $90 \%$ of patients who had a mean haemoglobin of $7.82 \mathrm{~g} / \mathrm{dl}+/$ Rate -2.27 .

The Focal Segmental Glomerulosclerosis (FSGS) was the most frequent histological finding, (five cases), followed by the specific combination lesions (hypertrophy and congestion of the glomerular and peritubular capillaries) (Figure1), the minimal glomerular lesions (LGM), membranoproliferative glomerulonephritis (MPGN) (Figure 2) and membranous glomerulonephritis (MGN).

The extra renal manifestations were: congestive heart failure (one case), hepatomegaly (one case), splenomegaly, and aquired skin pigmentation (one case). Serological tests for viral Hepatitis B, C and HIV as well as urine cytology performed on four patients were negative.

The therapeutic, angiotensin converting enzyme (ACE) inhibitors were indicated in all patients and haemodialysis was performed in one case. The evolution was marked by a PR in five cases, a CR in two cases. Three died as a result of congestive heart failure by hypokinetic cardiomyopathy.

\section{DISCUSSION}

Worldwide few studies have been devoted to the histological aspects of renal disease in sickle cell nephropathy, and even fewer in Sub-Saharan countries where the prevalence of the disease is higher $[4,5]$. This nephropathy is described in an homozygous form of the disease as well as in those carrying the sickle cell trait [5]. However sickle cell nephropathy occurs earlier in a homozygous form and its prevalence increases with age [6]. The average age of our biopsied sickle cell is compatible with that observed in sickle cell nephropathy in Sub-Saharan Africa [7, 8].

In our study - as well as the Maigné et al study which published nine cases of nephrotic syndrome out of 18 performed biopsies - the main indication for renal biopsy was nephrotic syndrome. However, reported prevalence of nephrotic syndrome in sickle cell disease is variable from $4 \%$ in the series of Bakir et al [9] to $20 \%$ in that of Fongoro et al [10].

The nephrotic syndrome was associated with macroscopic hematuria, as frequently described in literature $[1,5,8]$, or microscopic hematuria, often discovered by chance [5] as in our series. The nephrotic syndrome was associated with impaired renal function in more than half of our patients $(54 \%)$ and those of Maigné et al (61\%) [3]. This high prevalence of chronic renal failure in cohorts of biopsied sickle cell, is partly due to a selection bias of a limited number of patients and partly because of their recruitment mode in nephrology.

Hypertension is rare in the course of sickle cell disease [11]. This lower blood pressure recorded in sickle cell patients in the African-American population (3.2\%) compared to healthy individuals from the same population $(28 \%)$, is partly due to a peripheral release of endogenous vasodilator substances and partly the result of a loss of electrolytes $[1,5,12]$.

The specific lesions frequently described in the literature were the second achieved in our study $(27 \%)$. These specific injuries accounted for $17 \%$ of the pathological aspects of sickle cell nephropathy in Ile de France [3]. They are early onset, described at early age [3], unlike our patients (25.7 years). This finding is related to the higher frequency of vaso-occlusive crises with the occurrence of multiple organ complications with age.

MPGN was the third histological lesions in our study. Its prevalence is varied: One of two cases of renal biopsy was published in Nigeria [4] and five of 18 cases in Ile de France [3]. MPGN is often post infection [2, 3, 13], but infectious explorations were negative in our patients.

The LGM and GEM are rarely reported in sickle cell disease [14]. Their etiology is multiple autoimmune, infectious, and tumour drug [14]. Given the inaccessibility of extensive 
infectious explorations in our regions (cytomegalovirus, herpes) and immunological, we do not exclude a condition associated by chance.

\section{CONCLUSION}

The histopathologic findings of renal involvement in the course of sickle cell anaemia are various but the most frequent is focal segmental glomerulosclerosis. The renal needle biopsy seems to be worthy in all glomerular disorders, hence the need to re-examine the biopsy indication criteria in order to assess the prognostic value of the histological findings .

\section{REFERENCES}

1. Remy P, Galacteros F, Rein Et Hémoglobinopathies, Encycl Méd Chir (Editions Scientifiques et Médicales Elsevier SAS, Paris), Néphrologie-Urologie, 18-053L-10, 2001, 9 p.

2. The National Kidney Foundation Kidney Disease Outcomes Quality Initiative (NKF KDOQI) Clinical Practice Guidelines For Chronic Kidney Disease: Evaluation, Classification, And Stratification, American Journal of Kidney Diseases, 2002, 39:S1266.

3. Maigné G, Ferlicot S, Galacteros F, Belenfant X, Ulinski T, Niaudet P, et al, Glomerular Lesions In Patients With Sickle Cell Disease, Medicine (Baltimore), 2010, 89 (1):18-27.

4. Okoro BA, Okafor HU, Nephrotic Syndrome In Nigerian Children With Homozygous Sickle Cell Disease, East African Medical Journal, 1997, 74:819-21.

5. López Revuelta K, Ricard Andrés MP, Kidney Abnormalities In Sickle Cell Disease, Nefrologia, 2011, 31 (5):591-601.

Figure 1: Tubulopathy necrosis and congestion of peritubular capillaries Masson trichrome green light. Magnifying $x 200$

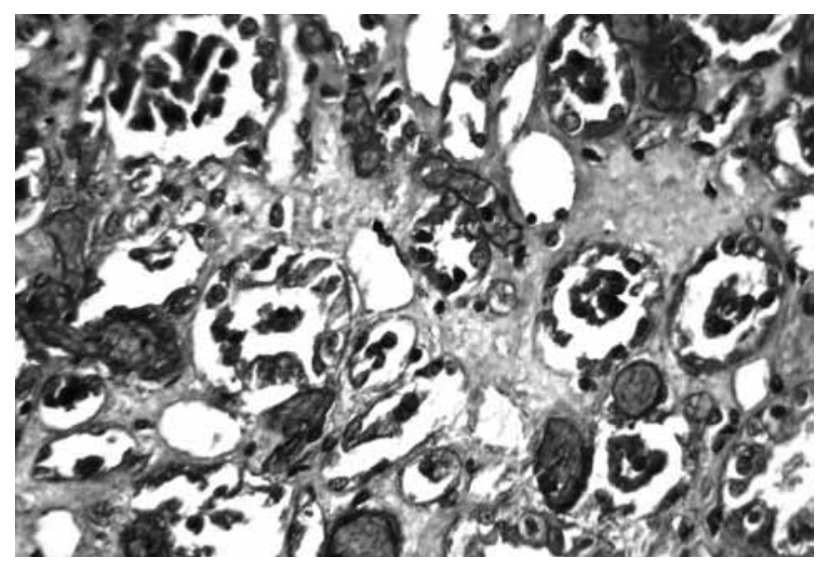

6. Shaw C, Sharpe CC, Could Sickle Cell Trait Be A Predisposing Risk Factor For CKD? Nephrology Dialysis Transplantation, 2010, 25:2403-5.

7. Abdu A, Emokpae MA, Uadia PO, Kuliya-Gwarzo A, Proteinuria Among Adult Sickle Cell Anaemia Patients In Nigeria, Annals of African Medicine, 2011, 10:3437.

8. Fall S, Seck SM, Cissé MM, Ndiaye FSD, Sarr GN, et al, Les Atteintes Rénales Associées À La Drépanocytose Homozygote SS À Dakar, Dakar Med, 2010, 55(3):1448.

9. Bakir AA, Hathiwala SC, Ainis H, Rheehl, Levy PS, Dune AG, Prognosis Of Nephrotic Syndrome In Sickle Glomerulopathy, American Journal of Nephrology, 1987, 7:110-115.

10. Fongoro S, Diallo D, Diallo DA, Tchiango KA, Maiga MK, Atteintes Rénales Associées Au Gène De La Drépanocytose Dans Le Service De Néphrologie Et D'hémodialyse Du CHU Du Point G, Mali Medical, 2009, 24 (2):53-56.

11. Scheinman JI, Sickle Cell Disease And The Kidney, Nature Clinical Practice Nephrology, 2009, 5 (2):788 .

12. Falk RJ, Prevalence And Pathologic Features Of Sickle Cell Nephropatby And Response To Inbibition Of AngiotensinConverting Enzyme, New England Journal of Medicine, 1992, 326(14):910-5.

13. Binaut R, Maisonneuve N, Vanhille P, Néphropathies Glomérulaires Orientation Diagnostique Et Evolution, EMC-Médecine 1, 2004, p110-20.

14. Ben Moussa F, Atteintes Rénales Au Cours De La Drépanocytose, In: Noël LH, editor. Atlas de pathologie rénale. Paris: Flammarion médecine-sciences, 2008, 574-85.

Figure 2: Membranoproliferative glomerulonephritis type I, lobulaire Masson trichrome green light. Magnifying x 200

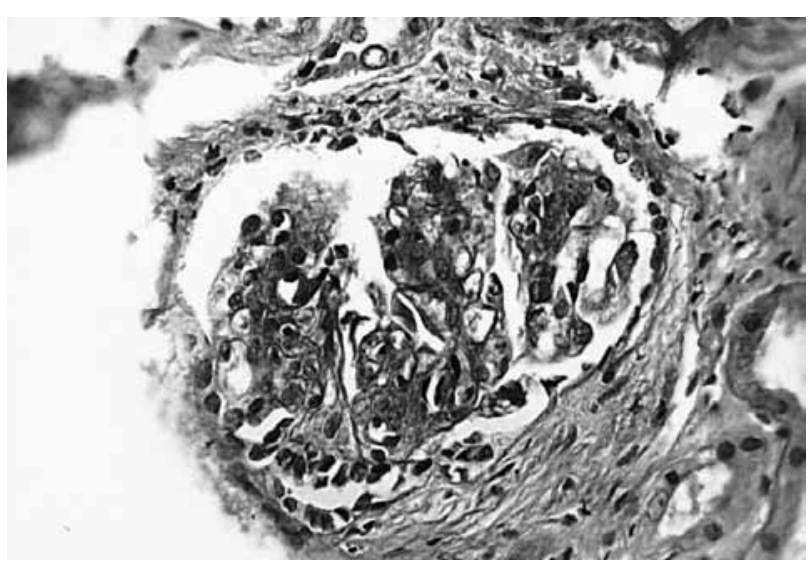


Table I: Diagnosis and histological characteristics of study's population

\begin{tabular}{|l|l|l|l|l|l|l|l|l|l|l|l|l|l|l|}
\hline Histo & Age & Sexe & SSD & VOC & BP & COMPL & HU & Hb & PU & ClCreat & HU m & ACE & PU Ev \\
\hline FSGN & 16 & F & SS & $>6$ & $110 / 60$ & Osteomyelitis & yes & 7 & 3,6 & 107 & yes & yes & PR \\
\hline FSGN & 29 & F & AS & & $100 / 80$ & & & 9,1 & 8 & 17 & yes & yes & CR \\
\hline FSGN & 13 & M & S $\beta$ Th & & & & & & & & & & & \\
FSGN & 17 & M & AS & & $110 / 60$ & & & 7,4 & 3 & 57 & yes & yes & Dth \\
\hline FSGN & 26 & F & AS & & $110 / 60$ & & & 11 & 6 & 100 & yes & yes & CR \\
\hline LGM & 13 & F & SS & $>6$ & $110 / 60$ & Cholelithiasis, CHF & & 7,6 & 3,5 & 186 & yes & yes & PR \\
\hline LGM & 51 & M & AS & & $130 / 80$ & & 12,2 & 7,93 & 15 & yes & yes & LS \\
\hline LGM & 13 & M & SS & $3-6$ & $120 / 80$ & & 7,8 & 5,5 & 177 & yes & yes & PR \\
\hline MPGN I & 17 & F & SS & $>6$ & $120 / 80$ & Femoral head necrosis & yes & 4,5 & 6 & 49 & yes & yes & PR \\
\hline MPGNI & 17 & M & SS & $3-6$ & $130 / 80$ & Osteomyelitis & & 6,4 & 4,58 & 124 & yes & yes & LS \\
\hline MGN & 43 & F & SS & $3-6$ & $140 / 90$ & Leg ulcer & & 5,2 & 13 & 78 & yes & yes & PR \\
\hline
\end{tabular}

MGN = Extra-Membranous Glomerulonephritis, FSGN = Focal Segmental Glomerulosclerosis, LGM = Minimal Glomerular Lesions, MPGN I = Membranoproliferative Glomerulonephritis type I, SSD = Sickle Cell Disease, VOC = Vasoocclusives Crises per year, $\mathbf{B P}=$ Blood Pressure, Compl $=$ Complications, $\mathbf{C H F}=$ Congestive heart failure, $\mathrm{HU}=$ Previous History of Hematuria, $\mathrm{Hb}=$ Haémoglobin Rate, $\mathrm{PU}=$ Proteinuria of 24h, $\mathrm{Creat} \mathrm{Cl}=\mathrm{Creatinine}$ Clearance, Hum = Microscopic Hematuria, ACE = Angiotensin Converting Enzyme, PU Ev = Proteinuria Evolution, CR = Complete Remission, RP = Partial Remission, PV = Lost Sight, Dth $=$ Death 